\title{
CONFLICTS PRESENT IN THE SAN JUANITO META MUNICIPALITY: A COMMUNITY PERSPECTIVE
}

\section{CASTRO GARZÓN HERNANDO ${ }^{1}$, RODRÍGUEZ MIRANDA JUAN PABLO ${ }^{2} \&$ RIVAS TRUJILLO EDWIN $^{3}$}

${ }^{\text {I}}$ Profesor. Escuela de Administración y Negocios. Facultad de Ciencias Económicas, Universidad de los Llanos, Villavicencio, Colombia

${ }^{2}$ Profesor Titular. Facultad del Medio Ambiente y Recursos Naturales. Universidad Distrital Francisco José de Caldas. Bogotá, Colombia

${ }^{3}$ Grupo de Investigación Interferencia Electromagnética (GCEM), Ingeniería Eléctrica, Facultad de Ingeniería, Universidad Distrital Francisco José de Caldas, Cra 7 No 40B-53, Bogotá, Colombia \begin{abstract}
This work analyzes the particularities that explain the conflicts present in San Juanito Meta municipality, especially after the declaration of excluded areas from economic use in rural zone, as well as the actions of agents with jurisdiction in the sector in front of the community. For this purpose, secondary information was collected as a baseline of information, establishing the areas of influence as well as agents and actors in the zone; which allowed establishing subcategories and descriptors to deal with the community of perceived conflicts that have been generating pressure for peasant subsistence in the territory. Conflicts were established over the use of water, forest resources, land tenure and loss of territorial affinity.
\end{abstract}

KEYWORDS: Protected Areas, Conflict, Community, Sustainability, Conservation

Received: Jun 08, 2020; Accepted: Jun 28, 2020; Published: Sep 25, 2020; Paper Id.: IJMPERDJUN20201420

\section{INTRODUCTION}

To start the discussion, it is necessary to establish that when talking about conflict, the social component is necessary (Krotz, 2019, p. 2), which may be of an environmental nature in the event that a dispute or incompatibility arises due to the disposition or use of a resource (Svampa, 2019, p. 98); given the diversity of interests present in an area or territory, whether private or public (Fernández-Labbé, 2020, p. 232). These, to be settled, a route must be designed for their approach and intervention (Pérez \& Mamani, 2020, p. 6); given that perceptions are different as positions on an event, also if they are produced between agents, agents and actors or different actors present in a jurisdiction (Garavito \& Díaz, 2020); establishing that the occurrence of a conflict is based on the particular appreciation of an interest and its position against it (Gil, 2019, p. 96).

It should be noted that conflicts are dynamic, appearing at different times, since resources are public goods, this is their character, as well as the affectation, generating responses from the actors when perceiving a detriment of the affected ecosystem good or service (Acacio \& Wyczykier, 2020, p. 460). It is associated with the different pressures exerted by the presence of common interests for the possession or use of environmental assets (Pérez, 2016, p. 122). On the other hand, their dynamics encompass various state actors, agents or entities 
that must be taken into account for their understanding and analysis, their relationship and impact, as well as the levels of power for each of them managed, as well as the environments in time, object of conflict (Lambin \& Thorlakson, 2018, p. 372).

Given their nature, resource conflicts pose their genesis in the distribution of the territory, since orographic forms do not correspond to real political, cultural or spatial designs since they are structured according to elements of thought or technical far from the contexts, what leads to conflicts (Bell, 2020 , p. 7); therefore the interpretation of territory is the fundamental element to settle or intervene those of an environmental nature (Vasquez, et al, 2020, p. 135); For the conception of territory, contextual interpretation is necessary, starting from ecosystem elements that define cultural ones, resulting in the different social appropriations of the territory (Ríos, 2020 , p. 8). It is active subjects and relationships that define the use and production of the floor finishing the different links of power in the same (Claeys \& Edelman, 2020, p. 22) stating that the construction of the same depends on different social elements that pervade, whether public, private, singular or community groups (Lima, et al, 2020, p.9); adding, that the use and distribution of the territory and its resources depends on the vision and cultural roots present, resulting in a series of appropriations such as exploitation of the resources in the existing one (Pavlo va \& Mikhaylova, 2020 , p. 459).

The aim of the work is to address the way in which the rural community of San Juanito municipality perceives and interprets the conflicts present in the municipality due to the presence of agents who have jurisdictions in their territory such as: the municipal mayor's office, the Regional Autonomous Corporation ( CORMACARENA), the Chingaza National Natural Park (PNNCH), the Bogotá Aqueduct and Sewer Company (EAAB) and that due to the theft of territories for protection purposes, they caused conflicts with the community present in this strategic territory.

\section{METHODOLOGY}

A mixed type investigation was carried out, since it began with an exploratory-descriptive method, consisting of identifying the properties where the socio-ecosystems are located, establishing their conflicts, classifying them, characterizing them and establishing their causes and impacts in the social, cultural and environmental aspects. Then some properties were analyzed and systematized for their understanding against the existing information and the institutional position; The inductive method was also applied for the analysis of cases, documents and files, in order to characterize them and identify how conflict situations have been addressed.

To "configure" (Bonilla \& Rodríguez, 2005, p. 135) the sample, previously secondary research processes were structured, field visits and contacts were made with agents and actors that intervene within the protected areas of San Juanito municipality; This led, in an inductive way, to begin to visualize the possible participants in the information gathering activities. To this end, in the work of Fossey, Harvey, McDermott \& Davidson (2002, p. 725) it is established that the sample must be adequate and sufficient referring to the representativeness of the individuals and the amount of information coined to answer the question of research and, therefore, describe the phenomenon studied.

Faced with the choice of actors, it was established as a strategy mix two forms of sampling such as: the intentional (Patton, 2006, p. 36) and the snowball (Goodman, 1961, p. 160). As actors, owners of properties located in the protection areas of San Juanito municipality were established. Intentional sampling "refers to a decision made in advance of the start of the study ... by informants who continue to have broad general knowledge about the topic to be investigated" (Bonilla \& Rodríguez, 2005, p.136). In addition to the above, in the snowball sampling "the participants are 
asked to identify other informants whom they know directly, whose characteristics fit the objectives of the study" (p. 139).

Informants who could establish details of the practices related to socio-ecosystems that are located in areas of influence were selected; Previous visits to the municipality were made in order to make contact with the population of interest and thus be able to address the research questions. The population of interest is made up of owners of properties located in the protection areas of the Chingaza National Natural Park and the Chingaza Páramo; For the purposes of the investigation, visits were made to the north, west and southeast of the municipality; the eastern zone was not visited because the properties are owned by the nation; there are no socio-ecosystems settled in these areas. This form of informant classification generates an aid to establish the sampling, in order to select people whose characteristics and activities allow the construction of sufficient and significant contents of the practice, in accordance with the objectives of the research; obtaining the information from the focus group tool, given the characteristics of the community, it was the most appropriate for the purposes of the work, starting from the conflicts subcategory and the descriptors meanings and experiences, the social phenomenon was addressed to generate a hermeneutic unit that will allow your analysis.

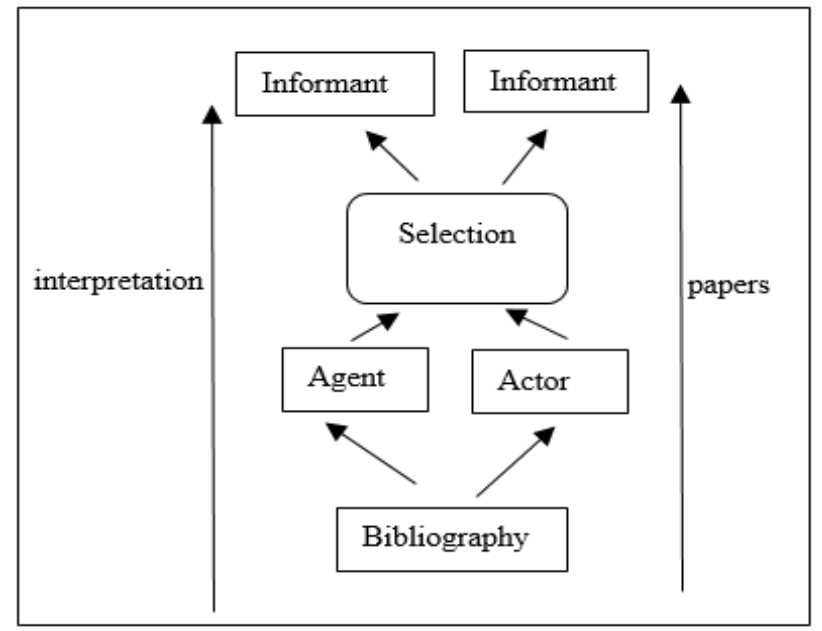

Figure 1: Strategy flow chart sampling. Own elaboration 2018.

\section{RESULTS}

Meanings and Experiences. The two descriptors are addressed to construct meaning in a clearer way since these, from the understanding of being mental constructs and therefore singular and subjective emotional ones, are configured in a narration of the lived events expressing the acquired and therefore shared experience; becoming a generator of relationships, in how it is described, since others act according to how significant it has been for each individual.

CORMACARENA Conflict: The forms of conversation are recognized through the broadcasts in the context, this discourse being a particular representation and a point of view defined and interacted from the individual feelings as shown below:

So far is when a corporation appears as CORMACARENA because we have banned to sow the same bean, we restrict long before there was never any kind of conflict, only the use of water, which suddenly someone was taking the water without permission, that the same community it could solve, all with the dialogue, and all we know and never has been disputes (Mora, Adonai).

It establishes a meaning of cohesive community for survival, in addition to proving it by putting its position 
before the restrictions of use, as well as determining that the genesis of the conflict is an agent of the State.

The environmental corporation is perceived as a punitive and coercive entity that prevents the development of work in the field, as can be seen: "if they tell us that we cannot knock down a tree without their permission, they should have an official to process the permit" and the predominant meaning entrenched in the experiences is reflected in the following:

The same prohibition to the cutting of wood, the license that does not provide, for example, ask for licenses to cut a tree, for the use of the aqueduct, concessions for use of water, for the quarries of sand or very small stone, on the banks of the river, the use for the roads, to build.

The interviewees establish a manifestation of direct involvement in the activities that represent their daily life.

Another feeling staged through their experiences is the Corporation's position vis-à-vis producers:

Here we can cut the trees and they don't even realize it, but it's not about that, we want them to help us find the solution to stop cutting the trees, and that can be done through a tutors project, all this area we spend a project with 169 users, for government support for the Environment Ministry, and CORMACARENA gave its verdict, that these people could not receive resources because we were planting in a protected area, but it was not about that, it was giving us the tools, take this and do this, but the only solution they give us is to back off the projects (Muñoz, 2018).

The community acquires a position in front of the conflict of interests generated, that the continuity of the conversation shows a dynamic position of the population in relation of these concrete proposals, but which degenerate in its accentuation.

The following words demonstrate fear of displacement:

They will say to the people that the project of $\mathrm{CO}^{2}$ was with immigration purposes, it is that we should go in times distant or that we should stop planting; But that would be done with an income of more than 3 million pesos where I can defend myself (García, 2018).

Always present the fear of eviction from your land, but the clarity of the statement about the amount of money gives way to a feeling of negotiation.

The feelings of provocation are predominant for some interviewees due to the role that the Corporation demonstrates:

They ask us to associate, if we associate, they say that they are many people, they pass the value of the project and they say that it is a lot of money, they put us in trouble for everything; The director told us that these projects cannot be financed (Gutiérrez, 2018).

The reactions to the lack of action of the environmental regulatory body, it should be clarified that the reactions are in the feeling and in the opinions, taking for granted the following premise: "In conclusion they bring us problems, not solutions. One is left bottled up, they want to be like getting us out of the municipality" (Muñoz, 2018). Once again the overwhelming appreciation of "getting us out" is presented, which is a repetitive statement in the interviewees, leading to a generalized position in the community regarding the actions of the Corporation: "It is rejection, because we want them to bring us something else, training and solutions" (Muñoz, 2018). 
The feelings and experiences of the participants are conducive to establishing that the agent that they see with the greatest discomfort and in whom the degree of confidence is the least is CORMACARENA, with whom they openly disagree with the proposals regarding forest management and exploitation, the water use and concession, as well as the respective permits for resource management.

Conflicts over Municipal Limits: The determining territorial limits in practice are unknown to informants; they plant particular positions:

Well, we don't really know that, that is another conflict since the border is not well defined, where is the limit of our department. There has not been decision, the mayor has sent statement to the Meta governor, but not has been reason (Muñoz, 2018).

It is the conviction, the posture in front of a macro territory as shown in the following section: "the limit should be the water, where the runoff ends, it should be the limit where the water begins to run" (Mora, 2018) showing that rooting is the one that refers to the inhabited territory, as well as the resources and events that occur in it. Therefore, it determines that they are in difference with a geopolitical neighbor who, due to the nature of the community, has not produced visible friction.

\section{Conflict with the Bogotá Aqueduct Company:}

In the spectrum of the use of the basin by foreign entities, the meanings are shown in the following intervention:

"The aqueduct first taken away our Guatiquía river, and we must receive something for that service because that service is ours" (García, 2018). The reference to the Bogotá Aqueduct and Sewer Company as a usurper is the prevailing sentiment in the community, precisely because of the iron concept of region and hydrographic basin already presented. The conception of territorial belonging is reaffirmed adding that the dynamizer of a future conflict is the economic content that would have the use of the waters of the Guatiquía river basin expressed as follows: "For the San Juanito inhabitants, it is clear that the waters of the Guatiquía river are from Meta, born in San Juanito. Those of Fómeque not claim anything, because there isn't one economic part they affect" (Muñoz, 2018), reaffirming the meaning:" At the moment their royalties for the aqueduct at that time they will claim "(Muñoz, 2018). "Those of Fómeque say that the lagoon is in their municipality" (Gutiérrez, 2018). A latent conflict is established between municipalities due to the use of an ecosystem service by a foreign agent that does not generate revenues for the communities or territorial entities; being the axis of the conflict the transfer of the Orinoco basin to the Magdalena basin by the Aqueduct Company of Bogotá.

On the other hand, the situation arises in front of the rural aqueducts, as soon as the Bogotá Aqueduct Company promised to improve them, this breach being the source of discontent, as shown below: "It would seem to me that this aqueduct being carried out, should the aqueduct keep, care for, we 're going to make the water more expensive of all side because the maintenance we get to do to us, should the same aqueduct keep it "(Muñoz, 2018) reaffirming the following position:" I did accounts and the amount of users there are not enough to support it, we are going to have to pay for the water as if we were in stratum six in Bogotá. Per cubic meter." (Muñoz, 2018). The aforementioned illustrates the position of the aqueduct company that is not very conciliatory with the community, once again demonstrating the passive reaction character of the informants that signify an affectation, but do not generate arguments leading to solutions. 
Continuing with the situation in front of the Bogotá aqueduct, the reel created in PNNCH jurisdiction is enunciated for its use: "The road that goes from the checkpoint to La Calera cannot be touched by us unless it is with permission" (Mora, 2018) showing that the road with the best access to the municipality has restrictions as well as particular benefits: "they are exclusively up to where they benefit them, if for example if I want to go through the road to La Calera I cannot travel on the motorcycle and if it is in car I have a permit three days in advance to be able to travel to La Calera "(Mora, 2018) and the transfer of responsibility in front of the road is expressed:" they are in charge of maintaining the road, because they are the ones who they use it"(Muñoz, 2018).

It denotes ignorance of the jurisdictions and regulations regarding the uses of protected areas; as well as an absence of communication and negotiations between entities since it is, in this case the municipality, the entity that must represent the community in front of an access road in better conditions and times than the south eastern exit.

Conflicts with the Mayor's Office: The mayor's office as the authority of the municipality does not clearly define conflicts, but it establishes the following:

"We feel helpless on the part of the Mayor's Office, there is no representation in front of the corporation, or National Natural Parks" (García, 2018). Marked to feel that it is accentuated in the following: "the projects that arrive here never go through the mayor's office, they are indifferent to us, they are not aware of who arrives in the territory and to do what, they do not find out anything, and we invite them, but they never come. " (Mora, 2018).

A minority role of the institutionality is described, with a perception of uneasiness regarding their actions that leads to a situation of total nonconformity vis-à-vis the figure of the Mayor, whom the majority supported in their election. There is a community disorientation and a sense of abandonment from part of the authorities.

Conflict with National Natural Parks: The main conflict present with the PNNCH agent about the properties inserted in the park area shows the following expression: " we are in a buffer zone for parks" (Muñoz, 2018).

The stated meaning that their properties are located in restricted areas is clear; the implication of the border lines and their restrictions are ultimately where there is no light for the informants; therefore, the meaning is appropriated according to the particular understanding; the expression "buffer zone" permeates as a restriction that for the population has the same meaning throughout the territory, this being its only clarity and perception. The relationship with the greater fauna, located in the PNNCH, generates a shock since the feeling of the peasants is that it affects their economic interests as shown below:

The Andean bear is also a conflict, since the bear eats cattle and sheep, it is not herbivore, I had sheep, they placed cameras, I asked them to watch the videos, but they never showed me, but my sheep ran out. They said they were dogs, but the trail showed that they were bears" (Gutiérrez, 2018).

The meanings against a protected and endangered species are specifically rejection; none of the interviewees showed a sense of safeguard against the species; on the contrary, they reacted violently against the animal and the expression is rooted in the damage inflicted by the species, specifically its livestock:

"Yes, there are several because I found traces of several, some bigger and others smaller., I kill several animals, everything that is close to the park they eat them" (Muñoz, 2018). "The subject is delicate because we kept track of 11 cattle that had been eaten, we found them eating the cattle (Mora, 2018). 
The perception of conflict in front of the PNNCH and the affectations generated by the species that live there basically focuses on the responsibility that the institution should assume for the economic losses caused by the Andean bear; As this represents a protected species in the park, this agent should answer for the damages by paying for the slaughtered animals; This situation is referenced in the interviews: if they pay, the situation is rectified and if not, the perception points to the sacrifice of the species.

As a conclusion against the meanings and experiences, the following section is presented:

If we had to pay a lot of things because the meeting has to be completely legal. The conflict in the long run, whether we own the lagoon or not, is the municipality that is receiving all the pressure, and CORMACARENA, Aqueduct, etc. are coming. we feel cornered, they tell us that the tutors' projects are worth a lot of money, and with that they fix us, we have the problem of the garbage dump up in the source of the only remaining healthy river and they don't give us any solution. We feel cornered, that we are making a hindrance (García, 2018).

It closes with an expression deeply rooted in the area "we are making a nuisance"; they are the feelings of the people present in the protection zones, since the regulatory agents in the territory see them as their enemy and not as those in charge of administering ecosystem services in the area; Furthermore, they feel the pressure that they exert by virtue of their regulatory management.

\section{CONCLUSIONS}

The State — as the regulator and administrator of the nation's assets - determines which territories are deemed to be capable of conserving the natural resources present in them, establishing Protected Areas, where it is considering the exclusion of all activities that are not conservation in these spaces. Adding that the producers settled in those regions establish their economies, whether they are subsistence or not, through the appropriation and use of the present biodiversity; in turn, if the use of ecosystem services is located within a protected area, the action is considered illegal. On the other hand, the position shown by the interviewees is that they have been left aside for making these decisions, showing the prevalence of a conflict when the conservation vision of the State is shown as a priority since different visions of appropriation of the territory and use of resources, since the communities that live there are from periods prior to the decision to remove these areas, locally affecting their production approaches. The clash between the different resolution actions that establish the limits of the protected areas — in this case Paramo and PNNCH—, which have been carried out without the community's agreement, creates the sentiments expressed in the interviews; the meaning created in relation to who will do it and how he will do it remains ambiguous, and from this ambiguity arise the positions expressed in front of a territory intervened by the state entity. The tensions created on conflicts between agents and actors have not generated actions to the detriment of the owners of the properties located in Protection Areas; The property acquisition plans do not previously contemplate a sanitation of said properties, only considered those who have legalized their possession are, and for the study area only five (5) have Real Estate Registration. There is no property purchase plan, only a prioritization strategy is registered, but under the premise of legality and not possession. Adding that the one who buys the properties is the Bogotá Aqueduct Company or by third parties that compensate in the Chingaza Park and not the direction of it since the resources it owns are for operation. 


\section{REFERENCES}

1. Acacio, J., \& Wyczykier, G. (2020). Expectativas públicas y conflictos sociales en torno a los hidrocarburos no convencionales en Argentina: algunos apuntes sobre Vaca Muerta. Izquierdas, (49), 457-477.

2. Bell, T. W. (2020). Ulex: Open Source Law for Non-Territorial Governance. Ulex: Open Source Law for Non-Territorial Governance, 1.pp. 2-23

3. Bonilla, E. \& Rodríguez. (2005). Más allá del dilema de los métodos. La investigación en ciencias sociales. 3ra. Edición. Grupo editorial norma. 3 da edición.

4. Fernández-Labbé, J. (2020). El territorio como espacio contradictorio: promesas y conflictos en torno a la actividad extractiva en Ecuador, Colombia, Perú y Chile. EURE (Santiago), 46(137), 225-246.

5. Claeys, P., \& Edelman, M. (2020). The United Nations Declaration on the rights of peasants and other people working in rural areas. The Journal of Peasant Studies, 47(1), 1-68.

6. Fossey, E., Harvey, C., McDermott, F., \& Davidson, L. (2002). Understanding and evaluating qualitative research. Australian and New Zealand. Journal of Psychiatry, 36(6), 717-732.

7. Garavito, C. R., \& Díaz, C. A. B. (2020). Conflictos socioambientales en América Latina: El derecho, los pueblos indígenas y la lucha contra el extractivismo y la crisis climática. Siglo XXI Editores.

8. Garcia, J. (2018). Entrevista focus group vereda el San Luis del Plan y San Luis de Toledo, San Junito Meta. Colombia.

9. Gil, A. G. (2019). Minería y movilizaciones sociales en Colombia: consultas populares y derecho al territorio. Politica y Sociedad, 56(1), 87-105.

10. Goodman, M.A, (1961). Snowball sampling. Annals of mathematical statistics, 32-148-170.

11. Gutiérrez, P. T. (2018). Entrevista focus group vereda el San Luis del Plan y San Luis de Toledo, San Junito Meta. Colombia.

12. Lambin, E. F., \& Thorlakson, T. (2018). Sustainability standards: Interactions between private actors, civil society, and governments. Annual Review of Environment and Resources, 43, 369-393.

13. Lima, A. R. A., González, J. S., Ruiz, M. D. C. S., \& Heck, R. M. (2020). Nursing interfaces in rural care: an integrative review. Texto \& Contexto-Enfermagem, 29.

14. Krotz, E. (2019). Sociedades, conflictos, cultura y derecho desde una perspectiva antropológica. Expropiación liber al. Un ensayo sobre la transformación de recursos locales en mercancías globales, 63(11), 03.

15. Pavlova, M. B., \& Mikhaylova, V. V. (2020). Influence of the Industry on Traditional Economy: in the Context of Social and Economic Development of Rural Territories (on the Example of the Village of Iyengra of Neryungrinsky District of the Republic of Sakha (Yakutia)). E\&ES, 459(6), 062036.

16. Patton, M.Q. (2006). Foreword: Trends and issues as context. Research in the Schools, 13 (1).

17. Pérez, S. Á., \& Mamani, K. C. (2020). Estrategias colaborativas para el abordaje de conflictos: espacios de diálogo en México, Perú, Colombia y Guatemala. serie documentos de trabajo $N^{\circ} 263$. Rimisp Santiago Chile. p. 21

18. Pérez, F. J. (2016). Medio Ambiente, Bienes Ambientales Y Métodos De Valoración (Environment, Environmental Goods and Valuation Methods). Equidad Desarro. ISSN, 1692-7311. Pp. 119-158

19. Mora, A. (2018). Presidente veredal. Entrevista focus group vereda el San Luis del Plan y San Luis de Toledo, San Junito Meta. Colombia. 
20. Muñoz, A. (2018). Entrevista focus group Vereda el San Luis del Plan y San Luis de Toledo, San Junito Meta. Colombia.

21. Muñoz, T. B. (2018). Entrevista focus group Vereda el San Luis del Plan y San Luis de Toledo, San Junito Meta. Colombia.

22. Muñoz, R. (2018). Entrevista focus group Vereda el San Luis del Plan y San Luis de Toledo, San Junito Meta. Colombia.

23. Ríos, M. A. G. (2020). Territory, Territorialization, Appropriation, Identity, City-Region. Territorios, (42), 1. Territorios 42 / Bogotá, 2020, pp. 1-24 ISSN: 0123-8418 ISSNe: 2215-7484.

24. Svampa, M. (2019). Las fronteras del neoextractivismo en América Latina: conflictos socioambientales, giro ecoterritorial y nuevas dependencias (p. 144). transcript Verlag.

25. Vasquez, J. J. C., Celaschi, F., Formia, E., Flores, R. I., León, R., \& Triana, N. R. (2020). Design and Territory: Emergencies and Conflicts. Strategic Design Research Journal, 12(2), 135-137. 
